\title{
Articles
}

\section{Diabetes mellitus and the incidence of hip fracture: results from the Nord-Trondelag Health Survey}

\author{
L. Forsén ${ }^{1 *}$, H. E. Meyer ${ }^{2 *}$, K. Midthjell ${ }^{3}$, T-H. Edna ${ }^{4}$ \\ ${ }^{1}$ National Institute of Public Health, Oslo, Norway \\ ${ }^{2}$ National Health Screening Service, Oslo, Norway \\ ${ }^{3}$ National Institute of Public Health, Verdal, Norway \\ ${ }^{4}$ Department of Surgery, Innherred Hospital, Nord-Trøndelag, Norway
}

\section{Abstract}

Aims/hypothesis. To study if people with Type I (insulin-dependent) or Type II (non-insulin-dependent) diabetes mellitus have increased risk of hip fracture. Methods. The study population consisted of 35444 people 50 years of age and older, attending a health screening in a Norwegian county. They were followed up with respect to hip fracture for 9 years, and 1643 new hip fractures were recorded.

Results. The relative risk of hip fracture for women with Type I diabetes compared with women without diabetes was 6.9 (95\% confidence interval 2.2-21.6) adjusted for age, body mass index and daily smoking. The relative risk for men was nearly the same, but not statistically significant. Among women 50-74 years of age with Type II diabetes for more than 5 years, the relative risk was $1.8(95 \%$ confidence interval
1.1-2.9). This increased risk persisted when insulintreated women were excluded from the analysis. After additional adjustment for possible medical consequences of diabetes (impaired vision, impaired motor abilities and history of stroke) the relative risk among women 50-75 years of age with Type II diabetes was reduced to 1.5 (95\% confidence interval 0.9-2.5).

Conclusion/interpretation. We found an increased risk of hip fracture in women younger than 75 years with Type I diabetes or with Type II diabetes of long duration. In older men, there was an increased risk associated with Type II diabetes of shorter duration. Whether the increased risk is attributed to reduced bone mass or to factors associated with falling has not been determined. [Diabetologia (1999) 42: 920-925]

Keywords Type I diabetes, Type II diabetes, osteoporosis, hip fractures, cohort studies.
Hip fracture constitutes a large health problem and there are many proposed and established risk factors for these fractures [1]. There is, however, controversy concerning the importance of a number of these risk factors [1]. The role of diabetes mellitus as a risk factor for osteoporosis and hip fracture is undecided [2-4]. Whereas most studies suggest that Type I (insulin-dependent) diabetes mellitus may cause reduced bone

Received: 4 January 1999 and in revised form: 29 March 1999

Corresponding author: L. Forsén, National Institute of Public Health, P. O. Box 4404, Torshov, 0403 Oslo, Norway Abbreviations: CI, Confidence interval, 95\%; RR, relative risk.

*The first two authors contributed equally to this work mass, the results concerning Type II (non-insulin-dependent) diabetes mellitus are conflicting [2-4]. Increased fracture risk in people with diabetes is reported in some $[2,5,6]$, but not all studies [7-9]. Only a few of these studies distinguish, however, between Type I and Type II diabetes in the analyses [7, 9].

We studied the association between Type I diabetes, Type II diabetes and hip fracture in a follow-up of a large, representative cohort of women and men attending a health screening with emphasis on diabetes mellitus in a Norwegian county.

\section{Subjects, materials and methods}

Study population. All residents 20 years of age or older in the ethnically homogenous Norwegian county of Nord-Trøndelag 
were invited to a health screening between January 1984 and 1 March 1986 [10]. For this study, all people 50 years of age or older who attended the screening and who were alive 1 March 1986 were followed for hip fracture for 9 years. Of 38305 eligible subjects, 35444 (92.5\%) attended the screening.

Variables. Those invited to the screening were asked to fill in a questionnaire at home about background factors and personal health, including a history of diabetes mellitus [10, 11]. At examination, a nurse checked the questionnaire, and height, weight, blood pressure and pulse were measured. Non-fasting blood glucose was measured in capillary blood (Reflocheck, Boehringer Mannheim, Mannheim, Germany), and all who stated that they had diabetes mellitus had a blood sample drawn for analysis of $\mathrm{HbA}_{1}$ (Corning Glytrac, Corning Medical, Palo Alto, Calif., USA). At the screening all participants received a second questionnaire that included questions about lifestyle, education etc. People who answered "yes" to the question on diabetes were given an extended questionnaire with additional questions about diabetes mellitus including age of onset and type of treatment (insulin, oral antidiabetic drugs, diet). This second questionnaire was returned by $81 \%$ of the diabetic people. As an approximation we defined Type I diabetes mellitus in people who were being treated with insulin and who had been diagnosed with diabetes by age 40 . Correspondingly, Type II diabetes was defined in people treated only by diet, in those treated with tablets (oral anti-diabetic drugs), and in insulin-treated people with an age of onset greater than 40 years. People with Type II diabetes were subdivided into those with duration of diabetes shorter or longer than 5 years. Diabetic people who did not return or had incomplete information on the second questionnaire were grouped as unclassified diabetes. Information about body mass index, self-reported smoking habits, physical inactivity, self-reported ill health, impaired vision, impaired motor abilities and history of stroke were available from the screening $[10,12,13]$.

Follow-up. All residents of Nord-Trøndelag with hip fracture are admitted to one of two county hospitals. The follow-up lasted from 1 March 1986 to 31 December 1995. Hip fracture cases were identified in computerised discharge lists by code 820, 9th revision of the International Classification of Diseases. For the period 1 March 1986 to 29 February 1989 all fractures were confirmed by review of the hospital medical record of the individual patient. For the period 1 March 1989 to 31 December 1995 fractures were confirmed by examination of the operation codes for all patients identified in the computerised discharge lists as having a hip fracture. Only the first hip fracture during the whole period from 1 March 1986 to 31 December 1995 among the people screened was used in the analysis (1197 hip fractures in women and 446 in men). A separate validation study was done at one of the hospitals for the 2year period 1992-93 by searching computerised discharge lists, operation protocols and medical records for hip fractures. Of a total of 313 hip fractures, we identified 286 (91.5\% of the hip fracture patients) in our study. All the hip fractures identified were correctly classified. Observation time was calculated from 1 March 1986 to date of hip fracture, emigration, death or 31 December 1995.

Statistical methods. The odds ratio of several health problems (yes or no) within the different diabetes groups compared with the non-diabetic group was adjusted for age and statistical significance by means of logistic regression. The relative risk (RR) of hip fracture in each diabetes group compared with the non-diabetic group was computed by means of Cox regression, adjusted first for age; then age and body mass index; and then age, body mass index and smoking. In addition we adjusted for some possible health problems connected with diabetes. To study the possible influence of insulin treatment among people with Type II diabetes, the same model was used in an additional analysis excluding those on insulin treatment. Finally we applied the same Cox regression models among all subjects with another classification of diabetes status: no diabetes, diabetes with insulin treatment, diabetes without insulin treatment. Age was included in the analyses as age at start of follow-up (1 March 1986).

\section{Results}

Among all women 50 years or older, $0.12 \%$ were classified as having Type I diabetes and $4.5 \%$ as having Type II diabetes, whereas we were not able to classify $1.2 \%$ due to missing data (Table 1 ). The corresponding figure for men was $0.18 \%$ for Type I diabetes, $3.5 \%$ for Type II diabetes and $0.9 \%$ for unclassified diabetes. In the age group 50-74 years, $5.6 \%$ of those we were able to classify had Type I diabetes and $94.4 \%$ had Type II diabetes. None 75 years or older had Type I diabetes, except for three men.

Subjects with Type II diabetes were in general heavier than those without diabetes, whereas those with Type I diabetes were not (Table 1). Compared with people without diabetes, those with diabetes smoked less, had poorer health, were less physically active, had a higher prevalence of impaired vision, impaired motor abilities and stroke.

Women with Type I diabetes had a sixfold increased risk of hip fracture compared with women without diabetes, even after adjustment for body mass index and daily smoking (Table 2). A similar increased risk was suggested in men with Type I diabetes but, because there was only one hip fracture case, the confidence interval was wide. When adjusting for some possible medical consequences of diabetes (physical inactivity, impaired vision, impaired motor abilities and history of stroke) the relative risk was reduced in women and lost the statistical significance in women with Type I diabetes compared with women without diabetes $[\mathrm{RR}=3.8,95 \%$ confidence interval (CI) 0.5-27.4].

Type II diabetes with a duration of less than 5 years showed no increased risk of hip fracture either in women (both age groups) or in men younger than 75 years of age. For men 75 years and older there was a twofold increased risk of hip fracture (Table 2), even after adjustment for the possible consequences of diabetes (data not shown).

Diabetic women younger than 75 years of age who had had Type II diabetes for more than 5 years, had a nearly twofold increased risk of fracture. This result remained even when women with insulin treatment (59 of 274 women) were excluded from the analysis ( $\mathrm{RR}=1.8,95 \%$ CI 1.1-3.0). When adjusting for physical inactivity, impaired vision, impaired motor 
Table 1. Number of hip fractures and prevalence of several baseline risk factors for hip fracture in the diabetes mellitus status groups ${ }^{\text {a }}$

\begin{tabular}{|c|c|c|c|c|c|c|c|c|c|c|c|c|c|c|c|c|}
\hline \multirow{2}{*}{$\begin{array}{l}\text { Diabetes } \\
\text { status }\end{array}$} & \multirow[t]{2}{*}{$n$} & \multirow{2}{*}{$\begin{array}{l}\text { No. of hip } \\
\text { fractures } \\
\text { (rate per } 1000 \\
\text { person-years) }\end{array}$} & \multirow{2}{*}{$\begin{array}{l}\text { Mean } \\
\text { age } \\
\text { (years) }\end{array}$} & \multirow{2}{*}{$\begin{array}{l}\text { Mean } \\
\text { BMI } \\
\left(\mathrm{kg} / \mathrm{m}^{2}\right)\end{array}$} & \multicolumn{2}{|c|}{ Daily smoking } & \multicolumn{2}{|c|}{ Subjective ill health } & \multicolumn{2}{|c|}{ Physical inactivity } & \multicolumn{2}{|c|}{ Impaired vision } & \multicolumn{2}{|c|}{ Impaired motor abilities } & \multicolumn{2}{|c|}{ History of stroke } \\
\hline & & & & & $\%$ & $\begin{array}{l}\text { Odds ratio }^{\mathrm{b}} \\
(95 \% \mathrm{CI})\end{array}$ & $\overline{\%}$ & $\begin{array}{l}\text { Odds ratio } \\
(95 \% \text { CI })\end{array}$ & $\overline{\%}$ & $\begin{array}{l}\text { Odds ratio }^{\mathrm{b}} \\
(95 \% \text { CI })\end{array}$ & $\%$ & $\begin{array}{l}\text { Odds ratio }^{\mathrm{b}} \\
(95 \% \mathrm{CI})\end{array}$ & $\%$ & $\begin{array}{l}\text { Odds ratio }^{\mathrm{b}} \\
(95 \% \mathrm{CI})\end{array}$ & $\%$ & $\begin{array}{l}\text { Odds ratio }^{\mathrm{b}} \\
(95 \% \mathrm{CI})\end{array}$ \\
\hline \multicolumn{17}{|l|}{$\begin{array}{l}\text { Women } \\
\text { Age } 50-74 \text { years }\end{array}$} \\
\hline No diabetes & 13685 & $565(4.5)$ & 63 & 27 & 23 & 1.0 & 39 & 1.0 & 9 & 1.0 & 13 & 1.0 & 16 & 1.0 & 2 & 1.0 \\
\hline $\begin{array}{l}\text { Unclassified } \\
\text { diabetes }\end{array}$ & 93 & $4(6.3)$ & 67 & 30 & 26 & $1.8(0.7-4.6)$ & 67 & $2.8(1.8-4.4)$ & 18 & $1.6(0.5-4.8)$ & 32 & $2.7(1.7-4.3)$ & 29 & $1.9(1.2-3.0)$ & 13 & $6.3(3.2-12.6)$ \\
\hline $\begin{array}{l}\text { Type II diabetes } \\
\leq 5 \text { years }\end{array}$ & 221 & $8(4.5)$ & 66 & 29 & 11 & $0.5(0.3-0.8)$ & 63 & $2.5(1.9-3.3)$ & 20 & $1.9(1.3-2.8)$ & 25 & $1.9(1.4-2.7)$ & 27 & $1.7(1.2-2.3)$ & 7 & $3.2(1.8-5.7)$ \\
\hline $\begin{array}{l}\text { Type II diabetes } \\
>5 \text { years }\end{array}$ & 274 & $20(10.1)$ & 67 & 30 & 13 & $0.7(0.5-1.1)$ & 67 & $2.8(2.1-3.6)$ & 23 & $2.3(1.7-3.0)$ & 30 & $2.2(1.8-2.7)$ & 29 & $1.7(1.3-2.3)$ & 7 & $3.5(2.2-5.7)$ \\
\hline Type I diabetes & 23 & $3(15.8)$ & 59 & 27 & 10 & $0.2(0.1-1.0)$ & 65 & $3.3(1.4-7.8)$ & 20 & $3.2(1.0-9.6)$ & 26 & $2.9(1.1-7.4)$ & 13 & $1.0(0.3-3.3)$ & 0 & - \\
\hline \multicolumn{17}{|l|}{ Age $75+$ years } \\
\hline No diabetes & 3831 & $547(22.7)$ & 81 & 27 & 4 & 1.0 & 55 & 1.0 & 32 & 1.0 & 30 & 1.0 & 32 & 1.0 & 7 & 1.0 \\
\hline Unclassified diabetes & 129 & $9(18.7)$ & 83 & 26 & 6 & $1.8(0.4-7.7)$ & 79 & $2.9(1.9-4.5)$ & 48 & $1.8(0.9-3.6)$ & 52 & $2.4(1.6-3.4)$ & 55 & $2.4(1.6-3.4)$ & 36 & $7.4(4.9-11.2)$ \\
\hline $\begin{array}{l}\text { Type II diabetes } \\
\leq 5 \text { years }\end{array}$ & 144 & $15(21.1)$ & 82 & 28 & 4 & $0.6(0.2-2.1)$ & 77 & $2.6(1.7-3.9)$ & 46 & $1.6(1.1-2.3)$ & 51 & $1.8(1.3-2.4)$ & 42 & $1.5(1.0-2.1)$ & 12 & $1.8(1.0-3.2)$ \\
\hline $\begin{array}{l}\text { Type II diabetes } \\
>5 \text { years }\end{array}$ & 196 & $26(28.0)$ & 81 & 27 & 6 & $1.3(0.7-2.5)$ & 72 & $2.1(1.5-2.9)$ & 36 & $1.2(0.9-1.6)$ & 43 & $2.0(1.6-2.5)$ & 42 & $1.5(1.1-2.1)$ & 9 & $1.3(0.8-2.3)$ \\
\hline Type I diabetes & 0 & & & & & & & & & & & & & & & \\
\hline \multicolumn{17}{|l|}{ Men } \\
\hline \multicolumn{17}{|l|}{ Age $50-74$ years } \\
\hline No diabetes & 13210 & $217(1.9)$ & 62 & 26 & 38 & 1.0 & 37 & 1.0 & 9 & 1.0 & 13 & 1.0 & 17 & 1.0 & 2 & 1.0 \\
\hline Unclassified diabetes & 84 & $1(1.7)$ & 66 & 26 & 50 & $1.8(0.7-4.6)$ & 60 & $2.3(1.5-3.6)$ & 22 & $2.8(0.9-8.4)$ & 18 & $1.3(0.8-2.4)$ & 25 & $1.4(0.9-2.3)$ & 7 & $2.5(1.0-6.2)$ \\
\hline $\begin{array}{l}\text { Type II diabetes } \\
\leq 5 \text { years }\end{array}$ & 148 & $0(0.0)$ & 66 & 27 & 31 & $0.8(0.6-1.2)$ & 60 & $2.4(1.7-3.4)$ & 15 & $1.7(1.1-2.8)$ & 20 & $1.5(1.0-2.3)$ & 30 & $1.8(1.3-2.6)$ & 8 & $3.0(1.6-5.6)$ \\
\hline $\begin{array}{l}\text { Type II diabetes } \\
>5 \text { years }\end{array}$ & 220 & $4(2.5)$ & 66 & 27 & 25 & $0.6(0.5-0.8)$ & 52 & $1.6(1.3-2.1)$ & 9 & $1.0(0.6-1.6)$ & 20 & $1.5(1.1-2.1)$ & 26 & $1.6(1.3-2.0)$ & 8 & $3.0(1.8-4.9)$ \\
\hline Type I diabetes & 28 & $1(5.2)$ & 60 & 25 & 15 & $0.2(0.1-0.8)$ & 43 & $1.4(0.7-2.9)$ & 0 & - & 36 & $4.1(1.9-9.0)$ & 29 & $2.1(0.9-4.9)$ & 7 & $3.9(0.9-16.6)$ \\
\hline \multicolumn{17}{|l|}{ Age $75+$ years } \\
\hline No diabetes & 2868 & $204(12.3)$ & 81 & 25 & 22 & 1.0 & 46 & 1.0 & 17 & 1.0 & 26 & 1.0 & 27 & 1.0 & 6 & 1.0 \\
\hline Unclassified diabetes & 74 & $2(7.2)$ & 82 & 26 & 17 & $0.7(0.3-1.9)$ & 65 & $2.0(1.2-3.3)$ & 31 & $2.1(0.9-4.9)$ & 42 & $1.9(1.2-3.1)$ & 42 & $1.8(1.1-2.9)$ & 15 & $2.6(1.3-5.1)$ \\
\hline $\begin{array}{l}\text { Type II diabetes } \\
\leq 5 \text { years }\end{array}$ & 95 & $10(21.8)$ & 81 & 26 & 13 & $0.5(0.2-1.0)$ & 60 & $1.6(1.0-2.5)$ & 29 & $1.8(1.1-3.0)$ & 31 & $1.4(0.9-2.3)$ & 44 & $2.1(1.3-3.2)$ & 12 & $1.8(0.9-3.7)$ \\
\hline $\begin{array}{l}\text { Type II diabetes } \\
>5 \text { years }\end{array}$ & 118 & $7(13.8)$ & 81 & 25 & 14 & $0.6(0.4-1.0)$ & 58 & $1.6(1.1-2.4)$ & 28 & $2.1(0.9-4.9)$ & 41 & $2.1(1.4-3.0)$ & 41 & $2.0(1.5-2.6)$ & 10 & $1.8(0.9-3.2)$ \\
\hline Type I diabetes & 3 & 0 & 78 & 26 & 0 & & 100 & - & 0 & - & 33 & $1.8(0.2-19)$ & 67 & $6.1(0.6-68)$ & 0 & - \\
\hline $\begin{array}{l}\text { a People comprise } \\
\text { classified into the } \\
\text { health screening ir } \\
\text { delag on } 1 \text { March }\end{array}$ & $\begin{array}{l}18596 \\
\text { pur d } \\
\text { Nord- } \\
86 . \mathrm{T}\end{array}$ & $\begin{array}{l}\text { emales and } \\
\text { betes statu } \\
\text { røndelag in } \\
\text { ey were foll }\end{array}$ & $\begin{array}{l}16848 \\
\text { group } \\
984-1 \\
\text { wed u }\end{array}$ & $\begin{array}{l}\text { ales. Th } \\
\text { i.e. } 93 \\
66 \text { who w } \\
\text { il } 31 \text { De }\end{array}$ & 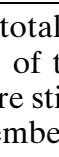 & $\begin{array}{l}\text { Imber tha } \\
\text { participa } \\
\text { iving in N } \\
995 \text { on hip }\end{array}$ & uld & $\begin{array}{l}\text { Each } \\
\text { variab } \\
\text { b Odd } \\
\text { sion }\end{array}$ & $\begin{array}{l}\text { calc } \\
\text { le } \\
\text { s ra }\end{array}$ & ation in the & & $\begin{array}{l}\text { is based on a } \\
\text { age and sign }\end{array}$ & 1 & $\begin{array}{l}\text { ects with inforr } \\
\text { e tested by mea }\end{array}$ & ation & $\begin{array}{l}\text { on the actual } \\
\text { gistic regres- }\end{array}$ \\
\hline
\end{tabular}


Table 2. Relative risk of hip fracture by type of diabetes mellitus. Nine-year follow-up of women and men attending the Nord-Trøndelag Health Survey

\begin{tabular}{|c|c|c|c|}
\hline Diabetes status & $\begin{array}{l}\text { Age adjusted only } \\
\text { RR }(95 \% \text { CI })\end{array}$ & $\begin{array}{l}\text { Adjusted for age and } \mathrm{BMI}^{\mathrm{b}} \\
\mathrm{RR}(95 \% \mathrm{CI})\end{array}$ & $\begin{array}{l}\text { Adjusted for age, BMI and daily smoking } \\
\text { RR }(95 \% \text { CI })\end{array}$ \\
\hline \multicolumn{4}{|l|}{ Women } \\
\hline $\begin{array}{l}\text { Age } 50-74 \text { years } \\
\text { No diabetes } \\
\text { Unclassified diabetes } \\
\text { Type II diabetes } \leq 5 \text { years } \\
\text { Type II diabetes }>5 \text { years } \\
\text { Type I diabetes }\end{array}$ & $\begin{array}{l}1.0 \\
1.1(0.4-2.9) \\
0.7(0.4-1.5) \\
1.7(1.1-2.7) \\
5.7(1.8-17.9)\end{array}$ & $\begin{array}{l}1.0 \\
2.0(0.8-5.4) \\
0.8(0.4-1.7) \\
1.9(1.2-2.9) \\
5.5(1.8-17.1)\end{array}$ & $\begin{array}{l}1.0 \\
2.3(0.6-9.2) \\
0.9(0.5-1.9) \\
1.8(1.1-2.9) \\
6.9(2.2-21.6)\end{array}$ \\
\hline $\begin{array}{l}\text { Age } 75+\text { years } \\
\text { No diabetes } \\
\text { Unclassified diabetes } \\
\text { Type II diabetes } \leq 5 \text { years } \\
\text { Type II diabetes }>5 \text { years } \\
\text { Type I diabetes }\end{array}$ & $\begin{array}{l}1.0 \\
0.6(0.2-2.5) \\
1.8(1.0-3.4) \\
1.1(0.6-2.5) \\
0\end{array}$ & $\begin{array}{l}1.0 \\
0.9(0.2-3.7) \\
1.8(1.0-3.7) \\
1.2(0.6-2.4) \\
0\end{array}$ & $\begin{array}{l}1.0 \\
0.0 \\
2.1(1.1-4.2) \\
1.2(0.6-2.6) \\
0\end{array}$ \\
\hline
\end{tabular}

35444 people with complete data (1643 hip fractures)

b 34355 people with complete data (1575 hip fractures)

c 29585 people with complete data (1313 hip fractures)

abilities and history of stroke, the relative risk was reduced to 1.5 (95\% CI 0.9-2.5). In older women with Type II diabetes of long duration an increased risk of fracture was only suggested, whereas men with Type II diabetes of long duration did not have increased risk of fracture, irrespective of age.

Poor control of diabetes defined as $\mathrm{HbA}_{1}>9.5 \%$ [14] was not associated with hip fracture risk in patients with Type II diabetes. Among hip fracture patients with Type II diabetes there were fewer with poor control at baseline than among those without fracture. For example, in women aged $50-74$ years with Type II diabetes of long duration the prevalence of poor control $\left(\mathrm{HbA}_{1}>9.5 \%\right)$ was $26 \%$ in the hip fracture patients compared with $49.8 \%$ in those without hip fracture. In Type I diabetes, among those with fracture there tended to be more with poor control but the number of patients were few. No clear association with fracture was evident in additional analyses where poor control was defined as non-fasting blood glucose greater than $10 \mathrm{mmol} / \mathrm{l}$ [14] (data not shown).

Table 3 shows the risks of hip fracture when an alternative classification of diabetes was used. In diabetic women younger than 75 years of age, those treated with insulin had a more than twofold increased risk of fracture, whereas a small and non-sig- nificant increased risk was found in diabetic women not treated with insulin. Among older diabetic women insulin treatment was rare (47 women used insulin of the 338 women who answered the question about insulin). Also among insulin-treated diabetic men younger than 75 years of age, there was a more than twofold increased risk of hip fracture, but the confidence interval was wide. Insulin treatment was rare among older diabetic men ( 15 men used insulin of the 214 men who answered the question about insulin) and no fracture occurred in this group. An increased risk of fracture was found in older diabetic men not having insulin treatment. This result corresponds with the result for diabetic men 75 years and older with Type II diabetes for less than 5 years (Table 2), of which $99 \%$ did not use insulin.

\section{Discussion}

We found an increased risk of hip fracture in women with Type I diabetes and a similar result was suggested in men. The younger women with Type II diabetes longer than 5 years also had an increased risk of fracture, whereas no increased risk was found in women with Type II diabetes of shorter duration. In the older 
Table 3. Relative risk of hip fracture by diabetes mellitus and insulin treatment. Nine-year follow-up of women and men attending the Nord-Trøndelag Health Survey ${ }^{\mathrm{a}}$

\begin{tabular}{|c|c|c|c|}
\hline Diabetes status & $\begin{array}{l}\text { Age adjusted only } \\
\text { RR }(95 \% \mathrm{CI})\end{array}$ & $\begin{array}{l}\text { Adjusted for age and BMI } \\
\operatorname{RR}(95 \% \mathrm{CI})\end{array}$ & $\begin{array}{l}\text { Adjusted for age, BMI and daily smoking } \\
\text { RR }(95 \% \mathrm{CI})\end{array}$ \\
\hline Women & & & \\
\hline $\begin{array}{l}\text { Age } 50-74 \text { years } \\
\text { No diabetes } \\
\text { Diabetes, insulin = no } \\
\text { Diabetes, insulin = yes }\end{array}$ & $\begin{array}{l}1.0 \\
1.2(0.8-1.8) \\
2.2(1.1-4.7)\end{array}$ & $\begin{array}{l}1.0 \\
1.4(0.9-2.1) \\
2.3(1.1-4.8)\end{array}$ & $\begin{array}{l}1.0 \\
1.4(0.9-2.1) \\
2.2(1.0-4.9)\end{array}$ \\
\hline $\begin{array}{l}\text { Age } 75+\text { years } \\
\text { No diabetes } \\
\text { Diabetes, insulin = no } \\
\text { Diabetes, insulin = yes }\end{array}$ & $\begin{array}{l}1.0 \\
1.1(0.8-1.5) \\
0.9(0.4-2.5)\end{array}$ & $\begin{array}{l}1.0 \\
1.1(0.8-1.6) \\
0.6(0.2-2.6)\end{array}$ & $\begin{array}{l}1.0 \\
1.2(0.8-1.7) \\
0.8(0.2-3.3)\end{array}$ \\
\hline $\begin{array}{l}\text { Men } \\
\text { Age 50-74 years } \\
\text { No diabetes } \\
\text { Diabetes, insulin = no } \\
\text { Diabetes, insulin = yes }\end{array}$ & $\begin{array}{l}1.0 \\
0.5(0.2-1.5) \\
2.4(0.6-9.9)\end{array}$ & $\begin{array}{l}1.0 \\
0.5(0.2-1.7) \\
2.5(0.6-10.2)\end{array}$ & $\begin{array}{l}1.0 \\
0.6(0.2-1.9) \\
3.1(0.8-12.4)\end{array}$ \\
\hline
\end{tabular}

${ }^{a}$ Diabetic people who did not answer the question about insulin were excluded from the analyses

b 35052 people (1624 hip fractures)

men an increased risk was found in those with Type II diabetes of short duration.

In this study we had no measurements to clarify the distinction between Type I and Type II diabetes, for instance $\mathrm{C}$ peptide and anti-GAD. Our approximation concerning patients not treated with insulin is reasonable because almost all patients treated with oral antidiabetic drugs or diet alone have Type II diabetes. These patients constitute $85 \%$ of all diabetic patients 50 years and older [15]. Our criteria for Type I patients could possibly misclassify some Type I patients, who acquired diabetes after 40 years of age, as Type II. Only a few Type II diabetic patients with an age of onset of less than 40 years would require insulin. Since the Type II diabetes results changed little when people using insulin were excluded from the analyses, misclassification of Type I into Type II would probably not, however, explain the increased risk associated with Type II diabetes found in this study.

Previous data on diabetes mellitus and fracture risk are limited and few studies deal with type and duration of diabetes [2]. In an American study, however, no increased risk of fracture was found in patients with Type I or Type II diabetes compared with matched controls (except for median malleolar fractures) [7]. In a follow-up study of women 65 years or older, a clear association between insulin-treated diabetes mellitus and proximal humerus fracture was found, whereas there was no such association with fracture of the distal forearm [6]. In a later study from the same cohort, an increased risk of hip fracture was suggested in diabetic women not treated with insulin, after adjustment for obesity $(\mathrm{RR}=1.6,95 \% \mathrm{CI}$ 0.9-2.7) [16]. In a follow-up study of middle-aged Norwegians, a noticeably increased risk of hip fracture was found in those with diabetes [5]. Although it was not possible to distinguish between Type I and Type II diabetes in that study, the review of the medical records of the hip fracture patients showed that all the diabetic patients with hip fracture had had diabetes since a young age or were treated with insulin or both. In a case-control study among elderly people in Oslo there was a non-significant increased risk for hip fracture in those with diabetes [17], whereas there were no increased rates for hip fractures and distal forearm fractures in diabetic women treated with insulin compared with fracture rates in the general population in a Danish study [8]. In a large cross-sectional study from Rotterdam, women with Type II diabetes had lower frequency of self-reported fractures in the preceding 5 years compared with non-diabetic women [9].

Our study did not include bone densitometry. Thus, we cannot evaluate if the increased fracture risk was mediated by reduced bone mass in the diabetic patients. Animal studies have shown that diabetes may cause reduced bone mass and decreased bone strength [3]. Studies in humans have reported reduced, normal or increased bone mass in patients with Type II diabetes [2, 3, 18]. In the large study from Rotterdam, both women and men with Type II diabetes had higher mean bone mineral density than the non-diabetic people, even after adjustment for obesity [9]. The majority of studies have found reduced bone mass in patients with Type I diabetes [2, 
3]. The reduction in bone mass, however, is in general modest with uncertain clinical relevance $[2,4,19]$. On the other hand, most studies are small and there are uncertainties concerning the effect of duration of diabetes and the metabolic control [2].

Whereas an effect of diabetes on fracture risk mediated by bone mass is undecided, increased risk of fracture could also be due to complications of diabetes predisposing to trauma (e.g. retinopathy, cerebral stroke, peripheral neuropathy) $[4,5]$. In our study the prevalence of impaired vision was higher in people with diabetes than in non-diabetic people. There was also an increased prevalence of stroke and impaired motor abilities. As shown by the multivariate analyses in women, the effect of diabetes seemed to be reduced when controlling for these possible medical consequences of diabetes. On the other hand, being overweight is associated with a reduced risk of hip fracture $[1,5,17]$. The greater prevalence of being overweight in people with Type II diabetes could thus be the reason for their reduced risk of hip fracture. This would explain why an increased risk is suggested when adjusting for body mass index in Table 2.

In addition to indicating poor control of diabetes, a high $\mathrm{HbA}_{1}$ measured at screening could also be associated with hyperinsulinaemia in patients with Type II diabetes. Insulin could act anabolically on bone tissue and a hyperinsulinaemic state could thus be associated with increased bone mass [2,9]. This could help explain the unexpected finding that Type II diabetic patients with hip fracture tended to have a lower prevalence of poor control than Type II diabetic patients without fracture.

The results for men with Type II diabetes were different from those for women as there was no tendency of increased risk associated with long duration of diabetes. On the contrary, in men 75 years and older an increased risk of fracture was associated with diabetes of duration shorter than 5 years. We do not have an explanation for this but mortality among these old men was very high during follow-up and, especially in this group, selective survival could interfere with the results. In addition, a general problem in men was a lower statistical power than in women due to a lower incidence of hip fracture.

In conclusion, we found an increased risk of hip fracture in women younger than 75 years with Type I diabetes or with Type II diabetes of long duration. In older men, there was an increased risk associated with Type II diabetes of shorter duration. To prevent fractures among diabetic people, it is important to explain whether the increased risk is attributed reduced bone mass, factors associated with falling or other unknown factors.

\section{References}

1. Cumming RG, Nevitt MC, Cummings SR (1997) Epidemiology of hip fractures. Epidemiol Rev 19: 244-257

2. Shane E (1996) Osteoporosis associated with illness and medications. In: Marcus R, Feldman D, Kelsey J (eds) Osteoporosis. Academic Press, San Diego, pp 925-946

3. Piepkorn B, Kann P, Forst T, Andreas J, Pfutzner A, Beyer $\mathrm{J}$ (1997) Bone mineral density and bone metabolism in diabetes mellitus. Horm Metab Res 29: 584-591

4. Bouillon R (1991) Diabetic bone disease. Calcif Tissue Int 49: $155-160$

5. Meyer HE, Tverdal A, Falch JA (1993) Risk factors for hip fracture in middle-aged Norwegian women and men. Am J Epidemiol 137: 1203-1211

6. Kelsey JL, Browner WS, Seeley DG, Nevitt MC, Cummings SR (1992) Risk factors for fractures of the distal forearm and proximal humerus. The Study of Osteoporotic Fractures Research Group. Am J Epidemiol 135: 477-489

7. Heath H, Melton LJ, Chu C (1980) Diabetes mellitus and risk of skeletal fracture. N Engl J Med 303: 567-570

8. Melchior TM, Sørensen H, Torp-Pedersen C (1994) Hip and distal arm fracture rates in peri- and postmenopausal insulin-treated diabetic females. J Intern Med 236: 203-208

9. van Daele PL, Stolk RP, Burger H et al. (1995) Bone density in non-insulin-dependent diabetes mellitus. The Rotterdam Study. Ann Intern Med 122: 409-414

10. Holmen J, Midthjell K, Bjartveit K et al. (1990) The NordTrøndelag Health Survey 1984-86. Purpose, background and methods. Participation, non-participation and frequency distribution. National Institute of Public Health, Community Medicine Research Centre, Verdal, Norway

11. Midthjell K, Bjørndal A, Holmen J, Krüger $\emptyset$, Bjartveit K (1995) Prevalence of known and previously unknown diabetes mellitus and impaired glucose tolerance in an adult Norwegian population. Indications of an increasing diabetes prevalence. The Nord-Trøndelag Diabetes Study. Scand J Primary Health Care 13: 229-235

12. Forsén L, Bjørndal A, Bjartveit K et al. (1994) Interaction between current smoking, leanness, and physical inactivity in the prediction of hip fracture. J Bone Miner Res 9: 1671-1678

13. Forsén L, Bjartveit K, Bjørndal A, Edna TH, Meyer HE, Schei B (1998) Ex-smokers and risk of hip fracture. Am J Public Health 88: 1481-1483

14. European NIDDM Policy Group (1993) A desktop guide for the management of non-insulin dependent diabetes mellitus (NIDDM). 2nd edn. World Health Organisation, European Region and International Diabetes Federation, Mainz, Kirchheim

15. Midthjell K, Holmen J, Bjørndal A (1994) Types of diabetes treatment in a total, Norwegian, adult population. The Nord-Trøndelag Diabetes Study. J Intern Med 236: 255-261

16. Cummings SR, Nevitt MC, Browner WS et al. (1995) Risk factors for hip fracture in white women. The study of osteoporotic fractures research group. N Engl J Med 332: 767-773

17. Meyer HE, Henriksen C, Falch JA, Pedersen JI, Tverdal A (1995) Risk factors for hip fracture in a high incidence area: A case-control study from Oslo, Norway. Osteoporos Int 5: 239-246

18. Rishaug U, Birkeland KI, Falch JA, Vaaler S (1995) Bone mass in non-insulin-dependent diabetes mellitus. Scand J Clin Lab Invest 55: 257-262

19. Compston JE, Smith EM, Matthews C, Schofield P (1994) Whole body composition and regional bone mass in women with insulin-dependent diabetes mellitus. Clin Endocrinol (Oxf) 41: 289-293 